\title{
THE EFFECT OF FLIPPED CLASSROOM TOWARD STUDENTS' ACHIEVEMENT IN TEACHING READING
}

\author{
Erwin Hari Kurniawan \\ FKIP Uniska Kediri, Indonesia \\ erwinharikurniawan@gmail.com \\ Sri Wulandari \\ FKIP Uniska Kediri, Indonesia \\ sw66941@gmail.com
}

\begin{abstract}
Flipped Classroom is a teaching strategy that combines technology in traditional teaching which today is commonly called blended learning. The flipped classroom is an opposite of traditional instructional procedures and usually done in the classroom in traditional learning to be performed at home in the flipped classroom, and usually carried out at home as homework in traditional learning to be implemented in the classroom in the flipped classroom. This research is aimed to knowhow students reading achievement can be improved by the effect of flipped classroom. To design this research, Action Research was chosen. There are two cycles on this research. Each cycle covered four steps; those were planning, implementing, observing and reflecting. The subject of this study was students in critical reading class consisting of 32 students. To gain the data, test, observation sheet, and interview were used. From the result analysis showed that the students reading achievement was improved by using flipped classroom. So, it was concluded that during the teaching and learning process students were more active and enthusiastic. They had good willingness in following reading class. In the last, it was recommended to use Flipped Classroom as the alternative strategy to teach reading.
\end{abstract}

Keywords: teaching strategy, blended learning, flipped classroom

\section{INTRODUCTION}

Reading is complex activity which involved encoding and decoding the language. According to Harmer (2007:99) reading is useful for language acquisition. Provided that students more or less understand what they read, the more they read, the better they get at it. Then, De Certeau (1984) states that reading is a complex "cognitive process" of decoding symbols in order to construct or derive meaning as in reading comprehension. Reading is a means of language acquisition, communication, and of sharing information and ideas. Like all languages, it is a complex interaction between the text and the reader which is shaped by the reader's prior knowledge, experiences, attitude, and language community which is culturally and socially situated. The reading process requires 
continuous practice, development, and refinement. In addition, reading requires creativity and critical analysis. Consumers of literature make ventures with each piece, innately deviating from literal words to create images that make sense to them in the unfamiliar places the texts describe. Because reading is such a complex process, it cannot be controlled or restricted to one or two interpretations. There are no concrete laws in reading, but rather allows readers an escape to produce their own products introspectively. This promotes deep exploration of texts during interpretation

The purpose for reading also determines the right approach to understanding the reading. Someone who needs to know if he can afford to eat at a restaurant definitely needs the pricing information provided on the menu, and no need to rename any. Someone reading poetry for fun needs to try the words poets use and the way they are put together, but not necessarily. However, people who use a scientific article to support an opinion need to know the vocabulary used, understanding the facts and sequences of ideas that are being thought and natures.

To add the statements before, Chun and Plass (1997: 60) based on L2's underlying theory of reading and understanding text with multimedia, discusses "how L2 reads more advanced research on cognitive processes involved in reading, that is, downstream diodes, Up like a process of vocabulary with a higher level, top-down process like activating prior knowledge ". They join this with existing research on learning with technology to find out how students with different learning abilities are put together "verbal and visual information". Their goal, in this study, is not to define multimedia capabilities on reading comprehension, trainers of learners who can benefit from multimedia instruction.

Learning strategy is one of the training programs that include the form and ability in learning. Learning strategies are structured for specific purposes. Learning strategy in it consists of approach, model, and learning method. According to Sanjaya (2007: 126), the world of education, strategy is defined as planning that contains about a series of activities designed to achieve certain educational goals. While Kemp (1995) describes the learning strategy is a learning activity that must be done teachers and students for the purpose to be effective efficiently and efficiently. From that opinion, Dick and Carey (1985) also mentioned the learning strategy is a set of materials and learning procedures used in conjunction with for student learning outcomes.

Based on the Dawson, Abesekera and Lakmal (2015), Flipped classroom is an instructional strategy and a type of blended learning that reverses the traditional educational arrangement by delivering instructional content, often online, outside of the classroom. It moves activities, including those that may have traditionally been considered homework, into the classroom. In a flipped classroom, students watch online lectures, collaborate in online discussions, or carry out research at home and engage in concepts in the classroom with the guidance of the instructor. The flipped classroom intentionally shifts instruction to a learner-centered model in which class time explores topics in greater depth and creates meaningful learning opportunities, while educational technologies such as online videos are used to deliver content outside of the classroom. In a flipped classroom, content delivery may take a variety of forms. Often, video lessons prepared by the teacher or third parties are used to deliver content, although online collaborative discussions, digital research, and text readings may be used. 
Flipped classrooms also redefine in-class activities. In-class lessons accompanying flipped classroom may include activity learning or more traditional homework problems, among other practices, to engage students in the content. Class activities vary but may include: using math manipulative and emerging mathematical technologies, in-depth laboratory experiments, original document analysis, debate or speech presentation, current event discussions, peer reviewing, project-based learning, and skill development or concept practice (Bergmann, and Sams, 2012). Because these types of active learning allow for highly differentiated instruction, more time can be spent in class on higher-order thinking skills such as problem-finding, collaboration, design and problem solving as students tackle difficult problems, work in groups, research, and construct knowledge with the help of their teacher and peers. Flipped classrooms have been implemented in both schools and colleges and been found to have varying differences in the method of implementation.

Emphasizing the theory of Flipped Classroom Alvarez (2011) a teacher's interaction with students in a flipped classroom can be more personalized and less didactic, and students are actively involved in knowledge acquisition and construction as they participate in and evaluate their learning. Related with the applied strategy, Flipped classroom is a reversal of traditional instructional procedures, which are usually done in the classroom in traditional learning to be performed at home in the flipped classroom, and which is usually carried out at home as homework in traditional learning to be implemented in the classroom in flipped classroom. Therefore, it is called inverted classroom learning.

In traditional learning, students are taught subject matter by teachers in the classroom (through lectures or direct explanations from teachers, group discussions, or reading and observing), then doing homework assignments (PR). In the contrary, in the flipped classroom, students study the subject matter at home (through watching video lessons, making summaries, noting key points, making inquiries, discussing with friends online, or reading needed sources), then working on tasks for reinforcement in the classroom. In the classroom there is also discussion, practice, explanation of concepts that students have not understood, but this is for strengthening or deepening.

In his book Flip Your Classroom: Reach Every Student in Every Class Everyday (2012), Bergmann and Sams write, "Basically the concept of flipped class is as follows: that which is traditionally done in the classroom is now done at home, and which is traditionally done as a home work is now completed in class." Based on the above exposure, the effect of flipped classroom can be used as a strategy in the pursuit of reading in UNISKA Kediri. Because it was found that the mean of students reading achievement were very poor. It was about under the 70. So, based on the statement above, the purpose of this study is to know how the students reading achievement can be improved by using Flipped Classroom.

\section{METHOD}

The design of this research was Action Research. According to Wardani et al. (2006: 1) action research is a form of self-reflective enquiry undertaken by participants (teachers, students or principals, for example) in social (including educational) situations in order to improve the rationality and justice of (a) their own social or educational practices, (2) their understanding of these practices, and 
the situations (and institutions) in which the practices are carried out. In this study, active participant was chosen, because the lecturer of critical reading is the researcher himself. So, it can be called as Collaborative Classroom Action Research. This research consisted of two cycles. Each cycle had four steps, those are: planning, implementing, observing and reflecting. The following detail explanation about the steps in each cycle, as follows:

Planning is the first step of the cycle which related with the teaching preparations that has been designed by the researcher. Preparing lesson plan that contained the instructional objectives to be achieved, the material to be taught and the task given to the students as the evaluation of the applied method. In addition, the researcher provided the questionnaire and observation sheet which used to collect the secondary data during the teaching and learning process as well as designing the criteria of success used in this research.

The next step is implementing. Implementing the plan that has been designed before with the application of Flipped Classroom method toward student's reading achievement. During the implementation, the researcher certainly did the observation before to gather the needed data in this research. It was important to decide the appropriate teaching and learning activities in designing the lesson plan that was applied in the classroom.

The third step is observing. Collecting the data during the teaching and learning process was taken in this step. The data were used as an indicator of achieving the criteria of success that has been targeted. The data were gotten from test, questionnaire and observation sheet that was prepared before.

Reflecting was the last step to gain the data. It was about analyzing the collected data during implementing Flipped Classroom method in teaching and learning process. It was done to determine whether the applied method gives the contribution or not with achieve the available criteria of success. If the data are coming up expectation of criteria of successes, it means that this cycle has been success and vice versa.

The subjects of this research were the fourth semester students of FKIP Bahasa Inggris, UNISKA especially in Critical Reading Class consisting of 32 students. The data were collected through a reading achievement test, observation sheet, and interview guide during the teaching and learning process.

\section{PROCEDURES OF RESEARCH IN EACH CYCLE}

The implementation of the researcher and students relate to the process of how the teacher guided the students to take part in the teaching and learning process through the implementation of the flipped classroom which consists of three phases of instruction namely pre-reading activities covered (planning), whilst-reading activities covered (monitoring and evaluation), and post-reading activities.

First, in pre-reading (planning) activity could be categorized as conveying learning objective, introducing the topic and activating the students' background knowledge. According to Grabe in Richard and Renandya (2002), activating schemata supports comprehension by calling up stable background knowledge representations that supports and interpret the text knowledge. To add the theory before, Wainwright (2007) states that by activating background knowledge and experience the students could easily understand the materials, because the broader 
this is, the more likely the students are to be able to tackle materials of greater difficulty drawn from a wider range of subject areas. Breadth of the scope breeds more breadth as well as greater depth of understanding. In short, eliciting the students' prior knowledge in advance will help them to comprehend the text easily.

In the pre-reading strategy, lecturer uploads teaching materials to the internet to be downloadable (in the padlet) and learned before the students enter the class (the format can be in the form of notes, videos, sound recordings and so fascinating and not learned). If there is no internet connection, then the mater can be shared by using flash, DVD, etc.

Second, in whilst-reading (monitoring and evaluation) activity, the researcher did some steps. The lecturer gives a brief review of the teaching with questions and answers about the material that has been presented on the internet, the lecturer asks the students to discuss the text according to the subject they have previously learned with their group. (Homework assignments are now done in the classroom), students are asked to present the results of their discussion to get responses or comments between groups, lecturers conduct reinforcement of students' learning outcomes. To add the materials that must students mastered, the research team uploaded the material gradually in the padlet.com. This is done using the site address www.padlet.com/erwinhari/criticalreading2017.

Third, post reading activity was the last phase of the procedure, this phase was aimed to guide students to make conclusion of lessons that they have learned and did the reflection of teaching and learning process. The lecturer assisted the students who got the difficulty in applying flipped classroom strategy by giving some questions related to the materials. Thus, by conducting this activity the lecturer could make the evaluation about the learning process. This is the reflective teaching. Reflecting teaching is an approach to teaching which is based on a belief that teachers can improve their understanding of teaching and the quality of their own teaching by reflecting critically on their teaching experiences and develop the skills of considering the teaching process thoughtfully, analytically, and objectively as a way of improving classroom practices (Richard, 2002).

Last but not least, the first cycle was not success. It meant that the students' reading achievement was still low. In other words, the teaching and learning process using flipped classroom needs to analyze again in the next cycle. So, the researcher did the second cycle which revised the whilst-reading activity. The activity related to lecturer gives a brief review of the teaching with questions and answers about the material that has been presented on the internet changed by the students must read the materials before the class and create the questions about the materials that has presented in the internet. Then, the students are grouped to solve the issue related the materials.

\section{RESULTS}

Based on the result of reading achievement test which was conducted in two cycles, each cycle consists of two meetings in the implementation of flipped classroom strategy was done on May 17, 2017. At the end of each meeting was administered reading achievement test. This part also showed the result of the students' reading achievement test, the result of observation sheets and interview 
toward the students' involvement during the teaching reading process. The description of result analysis is described below.

\section{Cycle One}

This part showed us about the data analysis of reading achievement in cycle one. To start the explanation the score of preliminary study was served.

Table 1: The Students' Individual Score in Preliminary Study

\begin{tabular}{cccc}
\hline No. & Score Range & Number of Students & Percentage \\
\hline 1. & $76-80$ & 4 & $12,5 \%$ \\
2. & $71-75$ & 6 & $18,8 \%$ \\
3. & $66-70$ & 13 & $40,6 \%$ \\
4. & $61-65$ & 7 & $21,9 \%$ \\
5. & $0-60$ & 2 & $6,2 \%$ \\
& Total & 32 Students & $\mathbf{1 0 0 \%}$ \\
\hline
\end{tabular}

Based on the table 1 showed that the students' preliminary test were taken by 32 students. 2 out of 32 students got $6.2 \%, 7$ out of 32 students got $21.9 \%, 13$ out of 32 students got $40,6 \%, 6$ out of 32 students got $18.8 \%$ and 4 out of 32 students got $12,5 \%$. Based on table 1 also, it can be concluded that only 4 students who are success or $12.5 \%$ and $87.5 \%$ are not success. Because the criteria of success are $75 \%$ of students got score more than 75 .

Table 2: The Students' Individual Score in Meeting 1 Cycle One

\begin{tabular}{cccccc}
\hline No. & Score Range & Number of Students & Percentage & \multicolumn{2}{c}{ Minimal Passing Grade 75\% } \\
\cline { 4 - 6 } & & & & Higher & Lower \\
\hline 1. & $76-80$ & 2 & $6.25 \%$ & 2 & 30 \\
2. & $71-75$ & 5 & $15.63 \%$ & & \\
3. & $66-70$ & 15 & $46.88 \%$ & & \\
4. & $61-65$ & 4 & $12.50 \%$ & & $\mathbf{9 3 . 7 5 \%}$ \\
5. & $0-60$ & 6 & $18.75 \%$ & & $\mathbf{6 , 2 5 \%}$ \\
\hline \multicolumn{7}{r}{} & Total & 32 Students & $\mathbf{1 0 0 \%}$ & & \\
\hline
\end{tabular}

Based on the table 2 showed the students' score in meeting 1 cycle one. There were 2 out of 32 students who got more than 75 . And more than 30 out of 32 students who got less than 75. It meant that it was much needed about the improvement because it was very so far away from criteria of success. So, the researcher needs to teach in the second meeting.

Table 3: The Students' Individual Score in Meeting 2 Cycle One

\begin{tabular}{cccccc}
\hline No. & Score Range & Number of Students & Percentage & \multicolumn{2}{c}{ Minimal Passing Grade 75\% } \\
\cline { 4 - 6 } & & & & Higher & Lower \\
\hline 1. & $76-80$ & 11 & $34.38 \%$ & 11 & 21 \\
2. & $71-75$ & 8 & $25.00 \%$ & & \\
3. & $66-70$ & 12 & $37.50 \%$ & & \\
4. & $61-65$ & 0 & $0.00 \%$ & & \\
5. & $0-60$ & 1 & $3.13 \%$ & & $\mathbf{3 4 , 3 8 \%}$ \\
\hline
\end{tabular}


Based on the table 3 above it showed about the students' improvement in reading achievement. The students who got more than 75 were 11 students or $34.38 \%$. Based on table 3 also, the students who got range score $61-65$ also zero. And only 1 student who got scores less than 60 . This was very good improvement. It was very good for the researcher to do the revising and do the next cycle.

\section{Cycle Two}

Because in the first cycle, the researcher did not success for improving the students' reading achievement, so the researcher did the second cycle to improve the reading achievement in teaching reading. The data showed in the table 4 and table 5 .

Table 4: The Students' Individual Score in Meeting 1 Cycle Two

\begin{tabular}{cccccc}
\hline No. Score Range & Number of Students & Percentage & \multicolumn{2}{c}{ Minimal Passing Grade 75\% } \\
\cline { 4 - 5 } & & & & Higher & Lower \\
\hline 1. & $76-80$ & 17 & $53.13 \%$ & 17 & 15 \\
2. & $71-75$ & 8 & $25 \%$ & & \\
3. & $66-70$ & 7 & 21.87 & & \\
4. & $61-65$ & 0 & $0 \%$ & & \\
5. & $0-60$ & 0 & $0 \%$ & $\mathbf{5 3 . 1 3 \%}$ & $\mathbf{4 6 . 8 7 \%}$ \\
\hline
\end{tabular}

Based on the table 4 above, it showed about the students' improvement. There were 17 students got more than the minimum passing grade. It was about $53.13 \%$ of the students have passed the grade. There were 0 students who got score in range $0-60$ and 61-65. It meant that the students who got minimum score are 0 . The 7 out of 32 students got $21,87 \%$ and the 8 out of the students got $25 \%$. So, in the first meeting of cycle two implied that the students are in the average score.

Because the first meeting of cycle two was also implied that it needed to do the second meeting. The reason is that the students' reading achievement does not pass the passing grade. If the minimum passing grade is $75 \%$ of students got the score at least 75 so the deviation between the first meeting and the passing grade is $21.87 \%$. It was about 7 students must got score more than 75 . After doing the second meeting, the researcher served the data on the Table 5 below.

Table 5: The Students' Individual Score in Meeting 2 Cycle Two

\begin{tabular}{cccccc}
\hline No. & Score Range & Number of Students & Percentage & \multicolumn{2}{c}{ Minimal Passing Grade 75\% } \\
\cline { 4 - 6 } & & & Higher & Lower \\
\hline 1. & $76-80$ & 28 & $87.50 \%$ & 28 & 4 \\
2. & $71-75$ & 3 & $9.38 \%$ & & \\
3. & $66-70$ & 1 & $3.12 \%$ & & \\
4. & $61-65$ & 0 & & & $\mathbf{1 2 . 5 \%}$ \\
5. & $0-60$ & 0 & $\mathbf{1 0 0 \%}$ & $\mathbf{8 7 . 5 \%}$ & \\
\hline \multicolumn{2}{r}{} \\
\hline
\end{tabular}

The table 5 showed that the students' reading achievement in teaching reading. There were 1 out of 32 students got $3.12 \%, 3$ out of the students got $9.38 \%$, and 
28 out of the students got $87.50 \%$. It meant that the minimum criteria of success were done. In other words, the researcher stopped the cycle and made simple conclusion about this research. Based on the table 5 above, it also showed that the improvement of students is presented. It was implied that the flipped classroom strategy can improve students' reading achievement.

\section{DISCUSSION}

Based on the research findings, it was revealed that student's reading achievement in teaching reading was successfully improved. It was to say that the flipped classroom strategy could improve the students' reading achievement in the teaching reading instruction of the fourth semester students of the English Department at FKIP UNISKA. It is also encouraged the students to be motivated in teaching reading process as well as built up their self confidence in learning.

The student's improvement in reading achievement using the flipped classroom strategy in current research can be shown by the students' average scores obtained from the preliminary study until the test conducted after implementing flipped classroom strategy as shown in Figure 1.

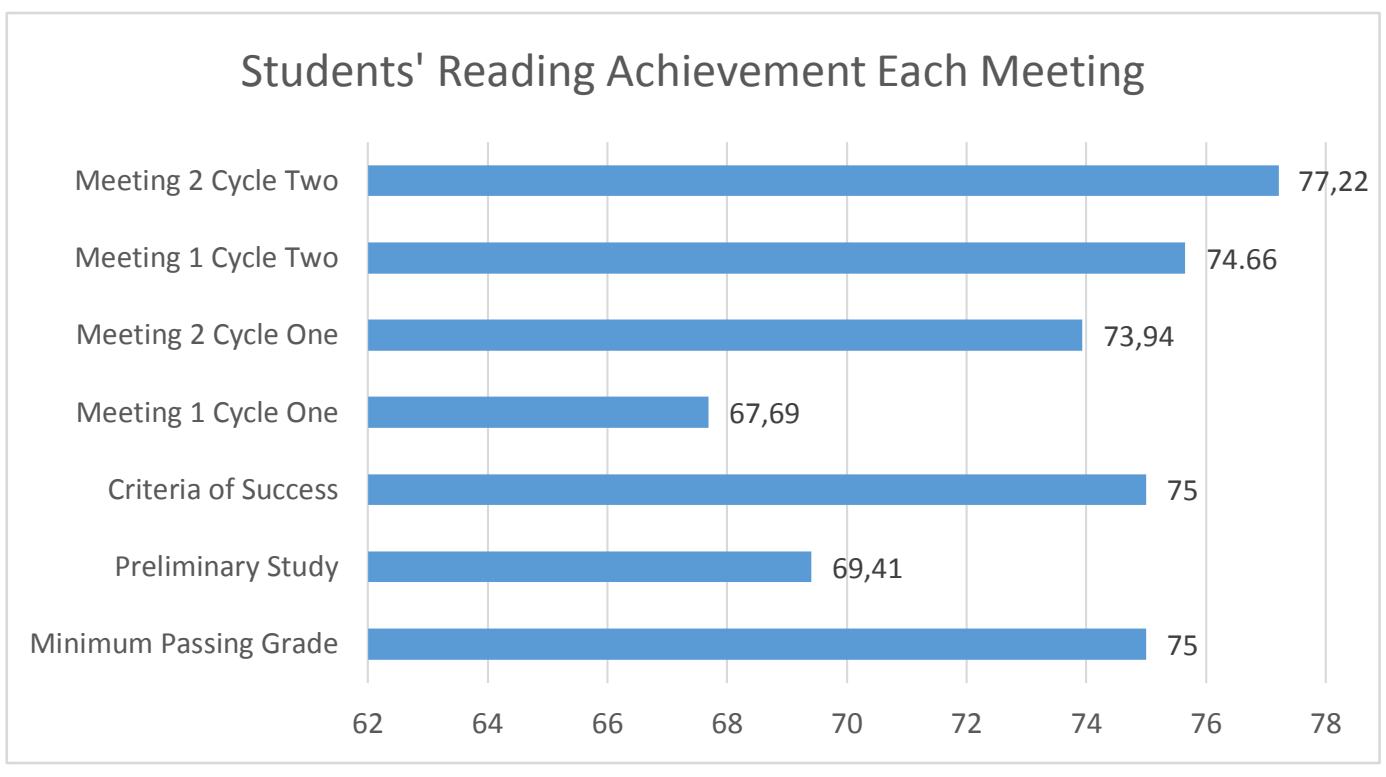

Figure 1: Students' Reading Achievement in Each Meeting

Based on the figure 1, it is obvious that the students' average score of reading achievement test in the preliminary study was 69.41 had successfully improved after implementing flipped classroom strategy as shown in the average score in the test conducted after the action of each meeting that we can view from the first and second meeting in cycle one was 67.69 and 73.94. It was also supported with the first and second meeting in cycle two was 74.66 and 77.22. Shortly, the Minimum Passing Grade (KKM) which had been set up in the planning of the action was 75. It had been achieved successfully in the test after the action. The determining of score 75 for the criteria of success is based on the reason that is stipulated by the researcher who considers the students' core before the action. The determining of the score 75.00 for students' reading achievement is based on the KKM stipulated by the faculty. 
The use of flipped classroom strategy in the current classroom action research has shown to be a successful strategy to improve reading achievement in teaching reading. Through the implementation of the strategy, the students were easy to understand the materials about reading covered about identify topic, main idea and supporting detailed information in the text; and to recognize the source of information to answer the reading achievement test in the reading instruction. The flipped classroom strategy also motivated the students to read the text gradually not only one-hour per day but also more than one hour per day.

Furthermore, it was easy for the students to identify the content of reading material, especially the topic, main idea and supporting ideas by employing the flipped strategy in teaching reading. The flipped classroom could improve their reading achievement as indicating their improvement of reading achievement. Moreover, in the current research, the improvement of the students' reading achievement in teaching reading was also triggered by the lecturer's modeling in applying flipped classroom strategy in teaching reading instruction. The conclusion is that flipped classroom strategy was really helpful to help the students understood how to understand the reading materials given by the lecturer in teaching reading process.

\section{CONCLUSSION AND RECOMMENDATION}

\section{Conclusion}

From this Research, there are some conclusions made:

1. The teaching strategies are: making an interesting video and uploaded into YouTube and linked in to Padlet. After that the teacher uploads supporting material used in the class. The students before the class should watch video linked in Padlet, make a note and questions relates to the material that they do not understand. They also download the pre-test file to be done in the class. Then during the class: the lecturer asks students to do the pre-test. After that, the students are given time to ask and answer the question that they get from the video presented. Then, the students should discuss the text given and present it to get suggestion and correction from others. The last the teacher gave reinforcement.

2. The function of quiz creator in pre-teaching in the class is to make students interest to learn the video presented on line, because it can stimulate their schemata toward the material to be discussed.

3. The use of Padlet makes students easy to manage the material presented without open YouTube or other links. It can focus the learning process in applying blended learning.

4. There is no homework given during applying the flipped classroom. The duty of the students is: watching and studying from the video and compare it with the hand out given.

5. The flipped classroom is alternative strategy that can be improved the students' reading achivement in teaching reading. 


\section{Recommendation}

The recommendations of this research are:

1. The presentation video made must be simple and interesting to be watched. The explanation and visual presented must be attractive and simple to make students easier to understand and interest to watch.

2. The use of pre-test in the class is useful to stimulate students to watch the presentation video. It was given before question and answer to stimulate their schemata.

3. Other researchers can conduct further study to develop this strategy for other subject or level of study with addition on the variable.

4. Other researchers can develop more varied strategy and teaching material based on the condition of the subject of research.

\section{REFERENCES}

Abeysekera, Lakmal, and Dawson, P. (2015). Motivation and Cognitive Load in the Flipped Classroom: Definition, Rationale and a Call for Research. Higher Education Research \& Development 34(1), page 1-14.

Alvarez, B. (2011). Flipping the classroom: Homework in Class, Lessons at Home. Education Digest: Essential Readings Condensed For Quick Review, 77(8), 18-21 retrieved from: $\quad$ http://neapriorityschools.org/successful-students/flipping-theclassroom-homework-in-class-lessons-at-home-2

Arfstrom, K.M. (2016). Flipped Learning Hand Out. retrieved from http://flippedlearning.org/wpcontent/uploads/2016/07/FLIP_handout_FNL_Web.pdf

Bergmann, J., \& Sams, A. (2012). Flip Your Classroom: Reach Every Student in Every Class Every Day. Washington, DC: International Society for Technology in Education.

Borg, Walter R and Gall, M.D. (1983). Educational Statistic. Longman: Michigan University

Chun, D. M., \& Plass, J. L. (1990). Research on Text Comprehension in Multimedia Environments. Language Learning \& Technology.

De Certeau, Michel. (1984). Reading as Poaching. The Practice of Everyday Life. Trans. Steven F. Rendall. Berkeley: University of California Press,. Page $165-176$

Garrison, R. \& Kanuka, H. (2004). Blended Learning: Uncovering its Transformative Potential in Higher Education," Internet and Higher Education 7, Page: 95-105.

Harmer. J. (2007). How to Teach English. Hongkong: Pearson Education Limited

Massie, E. (2002). Blended Learning: The Magic is in the Mix, in The ASTD ELearning Handbook, edited by A. Rossett . New York: McGraw-Hill, page 59

Sanjaya. W. (2006). Strategi Pembelajaran. Jakarta: Kencana Prenada Media Group. 